\title{
Stability of Transgenic Resistance Against Plant Viruses
}

\author{
Nikon Vassilakos \\ Benaki Phytopathological Institute \\ Greece
}

\section{Introduction}

Plant viruses constitute one of the main problems of the agricultural production worldwide (Kang et al., 2005). To date, there are not therapeutical measures available for the control of plant-virus diseases in the field and the main control strategy used in practice is based on prevention measures. Genetic resistance is by far the most effective way to control plant viruses. However, 'traditional' genetic sources of resistance to viruses are rare (Lecoq et al., 2004) and due to the high rate of mutation of the viral genomes this resistance even when applicable, is frequently broken under field conditions. The era of Agrobacterium-mediated genetic transformation of plants which started at the 80s (Thomashow et al., 1980; Zambryskiet al., 1980) offered new promising prospects for engineered genetic resistance to viruses with numerous following studies reporting a successful use of the transgenic technology against almost all genera of plant viruses or even viroids (Lin et al., 2007; Prins et al., 2008; Ritzenthaler, 2005; Schwind et al., 2009). However, mainly due to public concerns for the safety of using transgenic plants in agriculture only in a relatively small number of virus diseases transgenic technology has been used in the field and in these cases it was proved an efficient and safe way of control (Fuchs et al., 2007). The mechanism of resistance in the vast majority of the applications of transgenic-plant strategy is based on RNAsilencing. RNA-silencing is a sequence specific RNA degradation mechanism, highly conserved between kingdoms, which in plants, among other functions, operates as a natural antiviral defense system (Eamens et al., 2008). The role of RNA-silencing as an antiviral weapon has been further supported by the fact that almost every known plant virus species encodes for at least one protein with RNA-silencing suppression activity (Diaz-Pendon \& Ding, 2008). This knowledge raised the first concerns regarding the efficiency of RNAsilencing based resistance against viruses under field conditions. As silencing is sequence specific, the resistance of transgenic plants engineered to be resistant to typically one virus could be broken by a different, heterologous virus that could infect the plants in the field. The hypothesis was that the heterologous virus through its silencing suppressor protein(s) could repress the RNA silencing machinery of the plant as a whole, resulting in the loss of the initially engineered resistance. In addition, the extensive research on RNA-silencing that is going on for over a decade has revealed a number of environmental and plant physiological factors that can influence the silencing mechanism and consequently the effectiveness of RNA-silencing based transgenic resistance to viruses under field conditions. 
This review summarizes a fair amount of data that have been produced during the last decade in studies that have examined the role of heterologous viruses, the effect of temperature, the influence of the developmental stage of the plants in the stability of the transgenic resistance to viruses as well as recent findings for a direct effect of light intensity on the RNA silencing machinery. Moreover, new approaches for the implementation of RNA silencing in transgenic plant virus resistance are discussed as possible ways to overcome constrains of the current applications.

\section{Strategies for engineering resistance to plant viruses}

After the revolutionary work that was carried on Agrobacterium as a vector for plant transformation, the breakthrough for the creation of transgenic resistance to plant viruses came by Beachy's group which showed that the expression of the coat protein gene of Tobacco mosaic virus (TMV) in transgenic plants is conferring resistance to TMV (Abel et al., 1986). This discovery led the way for the production of an enormous number of transgenic plants resistant to viruses, using most types of viral genes. This genetically engineered resistance, referred to as pathogen-derived resistance (PDR) (Sanford \& Johnston, 1985), mechanistically was divided into two categories; protein mediated and RNA-mediated. In protein mediated resistance the transformation cassette is designed in such a manner that the introduced viral gene, most commonly either of the coat protein, the replicase or a defective movement protein gene, would be able to be translated and expressed into the plant and somehow interfere with the disassembly, the replication or the movement respectively, of the intruding virus. However, this division is rather simplistic as in most cases of resistance which were designed to be protein mediated, it was proved that multiple mechanisms were involved, most frequently the RNA-mediated one (Lin et al., 2007; Prins et al., 2008; Ritzenthaler, 2005). RNA-mediated resistance is related to RNA-silencing which is probably the most important and common strategy for engineered resistance to plant viruses and will be discussed more extensively below.

Besides the PDR strategy, alternative biotechnological approaches for the manufacturing of plants resistant to viruses include the expression of plant virus-resistance genes in other plants than those from which they were isolated (Farnham, 2006; Seo et al., 2006; Spassova et al., 2001) and the expression of peptides (Lopez-Ochoa et al., 2006; Rudolph et al., 2003; Uhrig, 2003) or antibodies. After the first successful application of the later strategy in 1993 by Tavladoraki and co-workers, with antibodies that reduced the susceptibility to Artichoke mottle crinkle virus using a single-chain variable fragment $(\mathrm{scFv})$ directed against the $\mathrm{CP}$ of the virus, technical difficulties hampered a wider application of this methodology. Nevertheless, several studies have reported the creation of plants resistant to viruses by expressing scFvs targeting structural as well as non-structural viral proteins (Binz \& Plückthun, 2005; Prins et al., 1995; Prins et al., 2005; Ziegler \& Torrance, 2002). The mechanisms of protein mediated resistance and of alternative methodologies are out of the scope of this review and will not be discussed further.

\section{RNA-silencing based transgenic resistance against plant viruses}

RNA silencing constitutes a vital element of the innate antiviral 'immune' response in plants. It uses cytoplasm-associated small interfering RNAs (siRNAs) to specifically target 
and inactivate invading nucleic acids. Besides siRNAs, a vast population of small RNAs (sRNAs) accumulates in plant tissues, which includes microRNAs (miRNAs), trans-acting siRNAs (ta-siRNAs), heterochromatin-associated siRNAs (also referred to as cis-acting siRNAs that are linked to transcriptional gene silencing) and natural antisense transcript siRNAs. These sRNAs through RNA silencing mediate repressive gene regulation and play important role in developmental control, preservation of genome integrity and plant responses to adverse environmental conditions, including biotic stress (Brodersen \& Voinnet, 2006; Chapman \& Carrington, 2007; Pasquinelli et al., 2005; Ruiz-Ferrer \& Voinnet, 2009; Vaucheret, 2006). To date, it has primarily been the cytoplasmic siRNA silencing pathway (also referred to as post transcriptional gene silencing, PTGS) that has been exploited by genetic engineering to confer resistance to plant viruses (Mlotshwa et al., 2008; Tenllado et al., 2004).

RNA silencing, is activated as a response to double-stranded RNA (dsRNA). Viruses, as well as transgenes, arranged as inverted repeats (IR), can directly produce dsRNA (which at a subsequent stage will give rise to primary siRNAs), whereas highly transcribed, sense orientated, single copy transgenes produce aberrant transcripts that serve as a substrate for producing dsRNA (subsequently processed to secondary siRNAs). In the latter case dsRNA is synthesized by one member of a family of cellular RNA-depended RNA polymerases (RdRPs) which counts six members in Arabidopsis (RDR1-6). Subsequently, the dsRNA can be targeted by a member of a group of Dicer-like ribonucleases (DCL1-4 in Arabidopsis) with each of them being involved in specific sRNA pathway(s) and generating specific size of sRNA duplexes (18-25nt in length). All four Arabidopsis DCL enzymes appear to be involved - directly or indirectly - in the production of siRNAs from DNA plant viruses, whereas the activities of DCL-4 and DCL-2 are mainly related to the production of siRNAs from single stranded RNA (ssRNA) viruses (Blevins et al., 2006; Ruiz-Ferrer \& Voinnet, 2009; Vaucheret, 2006, and references therein). dsRNA cleavage is facilitated by another group of dsRNAbinding proteins (HYPONASTIC 1or HYL 1 and DRB2-5 in Arabidopsis). Then, siRNAs are stabilized by 2 'O-methylation in their overhanging 3 'ends and exported to cytoplasm for PTGS. One selected sRNA strand together with one member of the ARGONAUTE (AGO) family of proteins form the core of a nuclease complex (RNA induced silencing complex, RISC) that targets and cleaves sequence-specifically homologous ssRNA (Ronemus et al., 2006; Ruiz-Ferrer \& Voinnet, 2009). The AGO family in Arabidopsis is predicted to contain ten members and for some of them a RNA slicer activity has been verified (Brodersen \& Voinnet, 2006; Chapman \& Carrington, 2007, and references therein). Many excellent reviews cover the functions of sRNAs and their role in RNA-silencing pathways in plants in great detail (Brodersen \& Voinnet, 2006; Chapman \& Carrington, 2007; Pasquinelli et al., 2005; Ruiz-Ferrer \& Voinnet, 2009; Vaucheret, 2006; Mlotshwa et al., 2008).

RNA silencing impedes viral multiplication in plants by two major ways. First it degrades the dsRNA intermediates of virus replication themselves as well as the cognate mRNAs (referred to as cell-autonomous silencing), a procedure that leads to the increase of accumulation of the respective siRNAs. Second, it generates a mobile signal that triggers the degradation of homologous mRNAs in distant cells (systemic silencing). This systemic branch of antiviral RNA silencing is related to siRNA population or their dsRNA precursors that move between neighboring cells through plasmodesmata and over long distances through the phloem (Kalantidis et al., 2008). 
RNA-silencing based resistance against viruses was first reported by Lindbo et al. (1993) and was shown to be related to the previously observed co-suppression mechanism (Napoli et al., 1990; Van der Krol et al., 1990). The following years, engineering of transgenic plants to harbor single-stranded sense and to a less extend antisense viral sequences became a common strategy to pre-activate the silencing machinery and obtain resistance against the homologous virus from which the introduced sequence has derived (Ritzenthaler, 2005). Further exploiting this knowledge led to constructing IR transgenes from which long double-stranded (ds) RNA precursors of siRNAs were directly generated. The utilization of such IR transgene constructs has become the method of choice for providing genetically engineered resistance to viruses because a single copy is sufficient to provide immunity, there is no expression of viral proteins, short genome incomplete sequences can be used and efficiencies of up to $90 \%$ of all transgenic plants produced to be resistant to the homologous virus were achieved (Lin et al., 2007; Tenllado et al., 2004; Ritzenthaler, 2005). In contrast to the situation with RNA viruses, the use of RNA silencing against DNA viruses most often resulted in delays in symptom development and did not always prevent virus replication (Lin et al., 2007). However, immune lines against Tomato yellow leaf curl virus (TYLCV) have been reported by Yang and co-workers (2004), and Fuentes and associates (2006).

In order to overcome the weakness of RNA-silencing based resistance [ineffective against viruses whose sequence differs from that of the transgene by more than $10 \%$ (Bau et al., 2003; Jones et al., 1998)], Bucher et al. (2006) fused 150-nt fragments of viral sequences of four tospoviruses in a single small chimeric IR construct. This strategy resulted in a high frequency of produced resistant plants. A most recent approach used modified plant miRNA cistrons to produce a range of antiviral artificial miRNAs (amiRNAs) (Niu et al., 2006; Qu et al., 2007; Schwab et al., 2006; Simon-Mateo \& Antonio Garcia, 2007; Zhang et al, 2011).

\section{Factors that influence the RNA-silencing based transgenic resistance}

\subsection{Heterologous viruses}

Since 1998 where the first viral suppressor of silencing was discovered it has been established that most known virus species carry at least one RNA silencing suppressor (Draz-Pendon \& Ding, 2008; Ding \& Voinnet, 2007). The awareness of this viral counterdefensive strategy against the innate antiviral defense system of plants guided several groups to investigate the effect that could invoke on transgenic resistance of plants that were immune to a virus, the infection with a different virus carrying a strong silencing suppressor.

The first studies were presented in 2001 by Savenkov and Valkonen, and Mitter and coworkers. Savenkov and Valkonen produced transgenic tobacco plants resistant to Potato virus A (PVA, genus Potyvirus) and examined whether the resistance to PVA was affected by infection of the transgenic plants with Potato virus Y (PVY), another potyvirus that was known to suppress RNA silencing through its HC-Pro protein (Diaz-Pendon \& Ding, 2008; Ding \& Voinnet, 2007). The PVY infection resulted in increased steady-state levels of the transgene mRNA in the transgenic plants. PVA challenge was followed 15 days after inoculation with PVY. In contrast to healthy (non-PVY inoculated) transgenic plants, in 
which no detectable infection with PVA was observed following challenge with PVA, all the PVY-infected transgenic plants were readily systemically infected by PVA. Moreover, in all PVA-infected plants, new leaves continued to display the severe symptoms, indicating no recovery from disease up to 90 days post inoculation. It was concluded that RNA-silencing mediated resistance in transgenic plants against viruses may be suppressed by infection of the plants with heterologous viruses that encode suppressors of gene silencing (Savenkov \& Valkonen, 2001). Not equally definite was the outcome from the studies of Mitter et al. $(2001 ; 2003)$ which showed that in transgenic tobacco plants, infection with Cucumber mosaic virus (CMV, genus Cucumovirus) expressing the silencing suppressor $2 \mathrm{~b}$ protein could transiently suppress the silencing mediated immunity to PVY but solely in new leaves that emerged after CMV inoculation and for a limited period of time. The experiments were carried out for six months and different time intervals were examined between the two virus inoculations. It was shown that longer periods of time between CMV inoculation and challenge of transgenic plants with PVY led to a larger proportion of PVY-susceptible plants. Nevertheless, in these plants the relative PVY titers tended to be lower as compared with untransformed control plants and the movement of PVY in the transgenic plants was restricted relatively to the controls. Most importantly, CMV infection supported only a transient PVY infection and did not prevent recovery of the transgenic plants. Moreover, reinoculation with PVY of the recovered plants or of plants that had been infected with CMV nine weeks earlier, failed to establish a PVY infection. Finally, although CMV infection resulted in increased transgene-derived mRNA levels in the leaves where breakdown of immunity had been recorded, the transgene-specific siRNAs levels were left unaffected.

Simon-Meteo et al. (2003) performed similar experiments on Nicotiana benthamiana plants that displayed RNA-silencing based resistance and were regenerated from recovered tissue of plants which showed a delayed resistance to Plum pox virus (PPV, genus Potyvirus). They used two heterologous viruses with distinct silencing suppressors, CMV and Tobacco vein mottling virus (TVMV, genus Potyvirus carrying an HC-Pro silencing suppressor). Each heterologous virus and PPV were inoculated either simultaneously or sequentially with an interval of two to four weeks onto transgenic plants. Both viruses, when applied sequentially, were able to reactivate transgene expression, but surprisingly, only the silencing suppression caused by CMV and not that originating from TVMV, was able to revert the transgenic resistant plants to a PPV-susceptible phenotype.

Taking into consideration these first studies several of the numerous succeeding reports (Fuentes et al, 2006; Germundsson \& Valkonen, 2006; Praveen et al, 2010; Kawazu et al, 2009; Yang et al, 2004) of engineered transgenic resistance to plant viruses have examined the possible effect of heterologous virus infection in the resistance. However, not always an influence on resistance was observed. Missiou et al. (2004) in transgenic potato plants resistant to PVY examined the effect on the resistance of Potato virus $X$ (PVX, genus Potexvirus, carrying the P25 silencing suppressor) infection simultaneously with PVY or one week prior to the challenge with PVY. In either of the two variations, infections with PVX occurred without a PVY infection to be detected. Similarly, resistance of transgenic cucumbers incorporating the $54 \mathrm{~K}$ polymerase domain of Cucumber fruit mottle mosaic virus (CFMMV) was not influenced by infection with the potyviruses Zucchini green mottle mosaic virus (ZYMV), Zucchini fleck mosaic virus (ZFMV), the ipomovirus Cucumber vein yellowing 
virus (CVYV) or CMV (Gal-On et al., 2005). In a different work, Lennefors et al. (2007) tested whether the high levels of RNA silencing-based resistance to Beet necrotic yellow vein virus (BNYVV) in transgenic sugar beet roots could be reduced by co-infection with common soilborne and aphid-borne beet viruses. The plants were first inoculated with the aphid transmitted Beet mild yellowing virus (BMYV), Beet yellows virus (BYV), or both viruses. Four weeks later, the plants were transplanted to soil infested with BNYVV, Beet soil borne virus (BSBV) and Beet virus $Q$ (BVQ) and their fungal vector, Polymyxa betae. The effectiveness of the resistance was not detectably compromised even following co-infection with all five viruses. Most recently, transgenic tobacco plants were produced, transformed with an IR construct corresponding to sequences of the TMV movement protein gene and the exhibited resistance to TMV was not affected by infection with CMV regardless of the order that the latter was inoculated (prior to or simultaneously with TMV) (Hu et al., 2011). In a different approach, amiRNAs expressed in tomato plants against CMV coding sequences resulted in resistance against the virus which was not noticeably affected by infection with TMV or TYLCV (Zhang et al., 2011). Moreover, the stability of transgenic resistance of tobacco plants against Tobacco rattle virus (TRV) (Vassilakos et al., 2008) remained largely unaffected by infection with CMV, PVY or Tomato spotted wilt virus (TSWV) (Vassilakos, unpublished results).

In contrast, in N. benthamiana plants expressing a Grapevine virus A (GVA) minireplicon and displaying high resistance to GVA, infection with Grapevine virus B (GVB, genus Vitivirus, carrying a P10 silencing suppressor) or PVY resulted in suppression of the GVA-specific defense (Brumin et al., 2009). Interestingly, in these tests GVA and GVB or PVY inocula were applied simultaneously as a mixture of saps derived from plants infected with the respective viruses, unlike previous studies, in which only sequential inoculations with the heterologous viruses resulted in reduced resistance. Finally, sweetpotato transgenic plants transformed with an IR construct targeting the replicase encoding sequences of Sweetpotato chlorotic stunt virus (SPCSV, genus Crinivirus) and Sweetpotato feathery mottle virus (SPFMV, genus Potyvirus) exhibited mild or no symptoms and virus accumulation was significantly reduced following SPCSV infection. However, development of severe sweetpotato virus disease symptoms (attributed to infection by both viruses) occurred in transgenic plants infected with a SPFMV isolate with a limited sequence similarity to the sequence used in the transgene (Kreuze et al., 2008).

The results from the studies that examined the effect of heterologous virus infection on the silencing-based transgenic resistance indicated that this kind of resistance, despite the immunity that can confer to the plants against a specific virus, could be compromised to some degree if applied in the field where mixed virus infections occur frequently. However, it became evident that the outcome of the interference between the heterologous viruses and the silencing machinery of the plant is not so easily predictable (Table 1).

The reasons for the discrepancies are unclear, but could be related to the mode of action of the viral suppression proteins of the different virus tested. Viral silencing suppressors are highly diverse in sequence, structure and activity, and could target multiple points in RNA silencing pathways whereas viruses with large genomes may encode several functionally distinct proteins to achieve silencing suppression (Diaz-Pendon \& Ding, 2008; Ding \& 
Voinnet, 2007). It is considered that suppressor proteins interfere either with siRNAs biogenesis or siRNA function without a multifunctional nature to be excluded. For instance, most studies agree that the potyviral HC-Pro probably specifically blocks accumulation of secondary siRNAs and leaves primary siRNA accumulation unimpaired, whereas P25 blocks accumulation of primary siRNAs (Diaz-Pendon \& Ding, 2008). In contrast, the $2 b$ protein of cucumoviruses directly sequestrate siRNAs duplexes using a pair of hook-like structures that interact more promiscuously with long and short dsRNA (Diaz-Pendon \& Ding, 2008; Ding \& Voinnet, 2007; Ruiz-Ferrer \& Voinnet, 2009). Additionally, it binds AGO1 and blocks slicing without interfering with sRNA loading in vitro. Although apparently contradictory, these two anti-silencing $2 \mathrm{~b}$ activities are reconcilable, because $2 \mathrm{~b}^{\prime} \mathrm{s}$ affinity for dsRNA is weak and its interaction with AGO1 could increase $2 b$ local concentrations and enhance specific binding to siRNAs (Ruiz-Ferrer \& Voinnet, 2009). Besides, Buchmann et al. (2009) reported that geminivirus AL2 and L2 proteins act as inhibitors of transcriptional gene silencing, which is the branch of silencing that targets DNA viruses.

Additional antiviral plant defense pathways could also be involved in the interference between the heterologous virus infection and the transgenic resistance or as yet unknown factors involved in specific virus species interactions. Thus, the CMV $2 \mathrm{~b}$ protein has been shown also to block silencing indirectly by interfering with the salicylic acid mediated defense pathway (Li \& Ding, 2001). Moreover, N. benthamiana plants transformed with an IR construct containing partial $N$ gene sequences from five tospoviruses [TSWV, Groundnut ring spot virus (GRSV), Tomato chlorotic spot virus (TCSV), Watermelon silver mottle virus (WSMoV) Tomato yellow ring virus (TYRV-t)] displayed resistance against all five viruses. However, co-infection of one of the tospoviruses with a genetically distant strain of the same species (TYRV-s), resulted in specific intraspecies breakdown of resistance through a procedure that involved complementation of the silencing suppressors of the two viruses (Hassani-Mehraban et al., 2009) (Table 1).

\subsection{Temperature}

It has been well known to plant virologists that temperature strongly influences plant-virus interactions. In high temperature, symptoms are frequently attenuated and virus titers in infected plants are decreased. In contrast, outbreaks of virus diseases are frequently associated with low temperatures (Hull, 2002).

Kalantidis and co-workers (2002) examined the influence of elevated temperature on siRNAs in CMV-resistant transgenic tobacco plants. Two transgenic lines, one expressing very high and the other very low levels of siRNAs, were tested for siRNAs concentration at $25^{\circ} \mathrm{C}$ and $32^{\circ} \mathrm{C}$ and at two time points, 20 and 30 days post-germination. At the early time point, transgene derived siRNAs could be detected only in the first line at $25^{\circ} \mathrm{C}$ and in both lines at $32^{\circ} \mathrm{C}$. However, in the first line transgene specific siRNAs were at $32^{\circ} \mathrm{C}$ in a significantly higher concentration compared to that of $25^{\circ} \mathrm{C}$. The analysis of samples taken at the second time point revealed the presence of transgene derived siRNAs in both lines at $25^{\circ} \mathrm{C}$. However, at $32^{\circ} \mathrm{C}$, siRNAs were detected in both plant lines at a higher concentration. Apparently, in these experiments, except for temperature the developmental stage of the plants also influenced the siRNA concentration (discussed further below). 


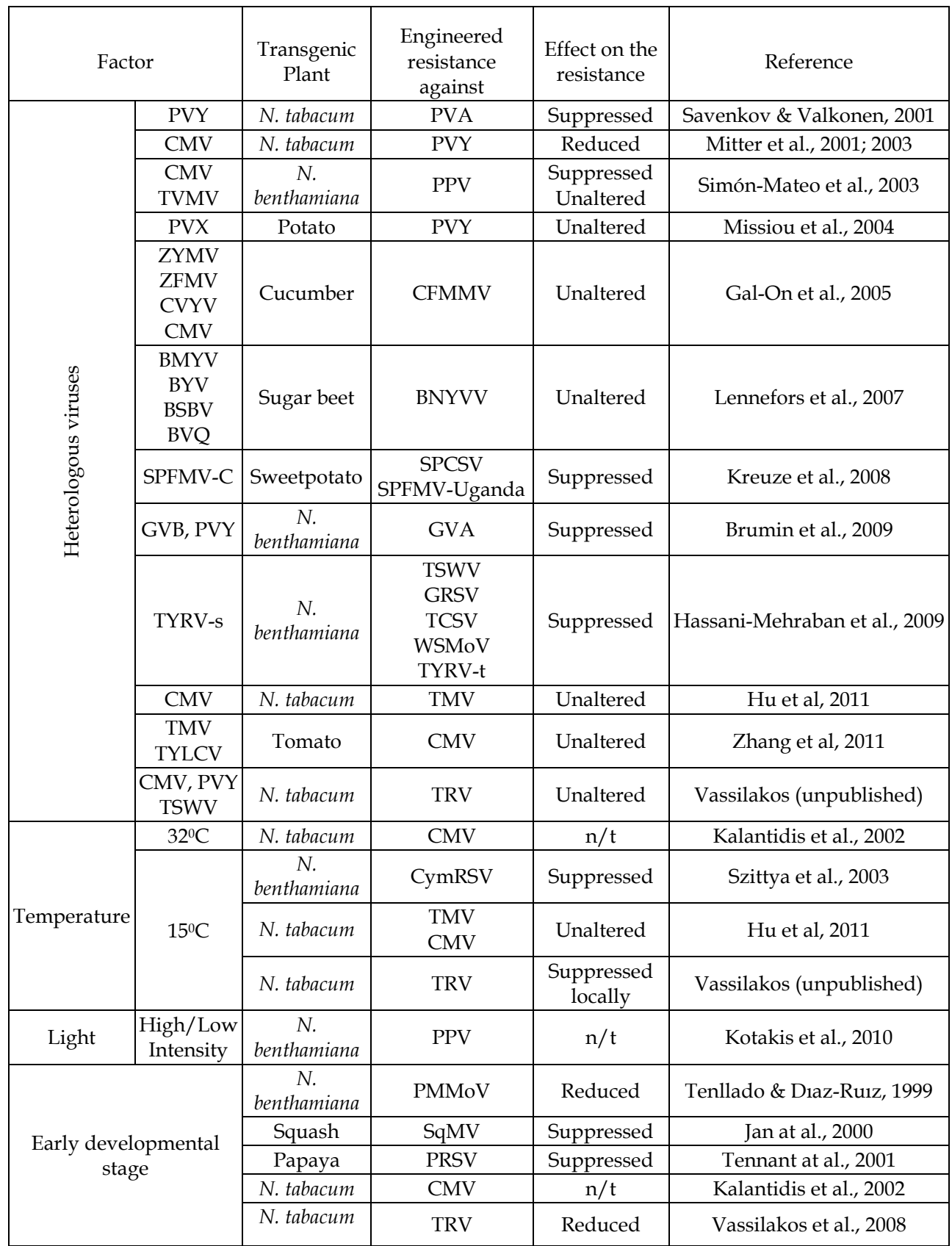

Table 1. Synopsis of the studies described in the text that involved experiments with transgenic plants resistant to viruses and the influence to the resistance of the various factors examined; $\mathrm{n} / \mathrm{t}$, not tested. 
Szittya and associates (2003) provided further insight into the mechanism that is involved in these observations. Through a set of delicate experiments they demonstrated that RNA silencing induced by viruses or transgenes is inhibited at low temperatures and enhanced with rising temperatures. They used wild type Cymbidium ringspot virus (CymRSV) encoding a p19 viral suppressor and a mutated one unable to express p19 (Cym19stop). In virus transfected $N$. benthamiana protoplasts, virus derived siRNA were undetectable at $15^{\circ} \mathrm{C}$ and gradually increased with temperature from 21 to $27^{\circ} \mathrm{C}$ indicating that virus-induced cellautonomous silencing is temperature dependent. The effect of temperature on virusinduced systemic RNA silencing was also examined. N.benthamiana plants were inoculated with CymRSV and Cym19stop and grown at different temperatures. CymRSV infected plants died within 2 weeks at 15,21 and $24^{\circ} \mathrm{C}$ whereas CymRSV symptoms were attenuated at $27^{\circ} \mathrm{C}$ and associated with reduced virus level. Confirming the role of p19 as a suppressor of systemic silencing, plants infected with the Cym19stop showed a recovery phenotype at 21 and $24^{\circ} \mathrm{C}$. At $27^{\circ} \mathrm{C}$, the mutant virus was unable to infect the plants, while at $15^{\circ} \mathrm{C}$, Cym19stop-infected plants displayed strong viral symptoms demonstrating that at low temperature, RNA silencing failed to protect the plants even when the virus lacked the silencing suppressor. In addition, using a strain of Agrobacterium tumefaciens carrying a green fluorescent protein (GFP) gene construct which was infiltrated sole or together with p19, to wt N.benthamiana or N.benthamiana plants expressing GFP, it was shown that transgene-induced silencing is also temperature dependent. The stability of RNA silencing mediated transgenic virus resistance at different temperatures was examined using transgenic N.benthamiana plants expressing a CymRSV-derived RNA. After inoculation with CymRSV the plants displayed strong resistance at $24^{\circ} \mathrm{C}$ whereas at $15^{\circ} \mathrm{C}$, severe symptoms were developed and CymRSV RNA accumulated to a high level demonstrating that the transgene-mediated virus resistance was broken at low temperature. A temperature effect was also observed on the antisense-mediated endogen gene inactivation of Arabidopsis and potato plants, in which antisense inhibition of genes involved in carbohydrate metabolism is broadly used. Interestingly, in contrast to siRNA production, miR157, miR169 and miR171 RNAs accumulated to equal levels at 15,21 and $24^{\circ} \mathrm{C}$ in arabidopsis suggesting that accumulation of miRNAs is not affected by temperature.

Chellappan and co-workers (2005) expanding the above findings quantified gemini virusderived siRNAs at different temperatures and evaluated their distribution along the virus genome for isolates of five species of cassava geminiviruses, consisting of recovery and nonrecovery types. In cassava plants, geminivirus-induced RNA silencing increased by raising the temperature from $25^{\circ} \mathrm{C}$ to $30^{\circ} \mathrm{C}$ and the appearance of symptoms in newly developed leaves was reduced, irrespectively of the nature of the virus. Consequently, high temperature rendered non-recovery type geminiviruses to recovery-type viruses. The distribution of virus derived siRNAs on the respective virus genome at three temperatures $\left(25^{\circ} \mathrm{C}, 25^{\circ} \mathrm{C}-30^{\circ} \mathrm{C}\right.$ and $\left.30^{\circ} \mathrm{C}\right)$ remained unaltered only for recovery-type viruses. siRNAs derived from recovery-type viruses accumulated at moderately higher levels during virusinduced silencing at higher temperatures. However, siRNAs from non-recovery-type viruses accumulated six times higher than those observed for infections with recovery-type viruses at high temperature. Thus, the decreased symptom severity and virus concentration that were recorded at higher temperature indicate a similar effect of temperature on ssDNA and RNA viruses although there was a differential effect of temperature on the level of virus-derived siRNAs between recovery and non-recovery types of ssDNA viruses. 
As with the effect of heterologous viruses, inhibition of RNA silencing or decreasing of siRNAs concentration in low temperature has not always been observed. Thus, transgene anti-sense induced RNA silencing was not inhibited in potato plants at low temperature (Sos-Hegedus et al., 2005). Moreover, tomato plants carrying an IR construct derived from Potato spindle tuber viroid (PSTVd) sequences and exhibiting resistance to PSTVd infection, did not show an elevated IR-siRNA accumulation at $31^{\circ} \mathrm{C}$ in comparison to $21^{\circ} \mathrm{C}$ (Schwind et al., 2009). In a more recent study, transgenic tobacco plants transformed separately with IR constructs corresponding to sequences of TMV movement protein gene or CMV replication protein gene, exhibited at both $15^{\circ} \mathrm{C}$ and $24^{\circ} \mathrm{C}$ similar high levels of resistance to TMV or CMV, respectively (Hu et al, 2011). In addition, the resistance against TRV of transgenic tobacco plants (Vassilakos et al., 2008) grown at $15^{\circ} \mathrm{C}$ was influenced only in the inoculated leaves but not systemically (Vassilakos, unpublished results).

In summary (Table 1), the well-known temperature effect on the development of viral diseases is closely associated to the RNA silencing antiviral pathway and consequently influences the efficiency of silencing-based transgenic resistance. However, it appears that the low temperature effect on the transgenic resistance depends on additional factors that remain to be identified, fact supported by inconsistencies in the results of the diverse studies described here. Importantly, although at low temperature the siRNA-based silencing machinery is partially inactivated as an adaptive response of plants to adverse conditions, the miRNA-mediated, which is essential for regulatory functions, continues to operate ensuring plant growth (Szittya et al., 2003).

\subsection{Light}

Studies on the effect of light on transgenic resistance to viruses are not available, however light has been implicated as one of the factors that affect RNA silencing initiation and maintenance in several studies. Although in most of them light effect on silencing was not clearly isolated from that of temperature (Nethra et al., 2006; Vaucheret et al., 1997) recently, Kotakis et al. (2010) investigated solely the role of light intensity in physiological ranges on RNA silencing. They used as a system $N$. benthamiana transgenic lines engineered to express GFP, which exhibited spontaneously silencing at different frequencies and of different spreading intensities. The authors demonstrated that high light intensity increased the frequency of plants displaying both short range and systemic silencing. In contrast, plants grown under low light conditions, showed lower silencing frequencies. In addition, increased light intensity positively affected siRNA levels corresponding to the GFP transgene (sense) transcript. In a different set of experiments, $N$. benthamiana plants were used, incorporating an IR structure derived from the NIb gene of Plum pox virus (PPV) and it was shown that levels of all distinguishable siRNA classes corresponding to the IR transcript were also positively affected by high light intensity (Table 1). Although in the latter case, the effect of light intensity on virus resistance was not tested, the authors proposed that light conditions comprise an additional environmental factor that should be taken under consideration when transgenic technology against viral infections applies on the field.

\subsection{Plant developmental stage}

Quite a few studies with plants carrying sense transgenes and displaying RNA-silencing mediated resistance have suggested an influence of plant developmental stage on the degree 
of the expressed resistance. Tenllado and Diaz-Ruiz (1999) reported that a higher percentage of transgenic $N$. benthamiana plants, transformed with the $54 \mathrm{~K}$ read-through domain of the replicase gene of Pepper mild mottle virus (PMMoV), displayed complete virus resistance at maturity than at an earlier stage of development. Subsequently, Jan et al (2000) demonstrated that a recovery type of resistance, in squash genetically transformed with the coat protein genes of Squash mosaic virus (SqMV), was due to RNA silencing that was activated at a later developmental stage, independently of virus infection. However, a different phenotype of complete resistance was not altered after SqMV inoculation at early developmental stages. Moreover, analysis of crosses between lines exhibiting complete resistance, recovery and susceptible phenotypes revealed that the time of activation of silencing, besides the developmental stage, is affected by the interaction of transgene inserts. Similarly, transgenic papaya plants were susceptible to Papaya ringspot virus (PRSV) at a younger stage but resistant when inoculated at an older stage (Tennant et al., 2001).

As mentioned already, Kalantidis and associates (2002) showed that siRNA accumulation in transgenic tobacco, incorporating an IR construct carrying CMV sequences, was higher at later developmental stages. No significant differences in the siRNA concentration were observed between leaves of different age from a single plant or from the seven-leaf stage on, while the siRNA concentration reached a plateau that remained stable in the course of further development.

In a more recent work, $N$. tabacum plants were transformed with the 57-kDa read-through domain of the replicase gene of TRV and were highly resistant to homologous (to the transgene sequence) TRV isolates and moderately resistant to the genetically distinct TRVGR. Very young transgenic plants with detectable levels of transgene transcript were resistant only systemically to homologous isolates and were susceptible to TRV-GR. Conversely, older plants (at a five-leaf stage) containing a low steady state level of transcripts were immune to homologous isolates and displayed moderate resistance against TRV-GR (Vassilakos et al., 2008).

In conclusion (Table 1), most studies agree that younger transgenic plants accumulate reduced amounts of transgene specific siRNAs compared to older ones, or correspondingly accumulate higher amount of transgene specific transcripts suggesting a reduced efficiency of transgenic resistance against plant viruses. However, the resistance phenotype was not always affected in younger plants, possibly due to reasons associated with the type of the transgene construct used, its integration into the plant genome or the viral sequences that are targeted.

\section{Conclusion}

A great deal of progress has been made towards comprehension of plant virus biology and the ways in which plants defend themselves against these pathogens. RNA silencing has provided a promising potential for generating virus-resistant transgenic plants and this potential is certainly not cancelled by the awareness of factors that may affect under specific conditions the acquired resistance. However, as with any other pathogen control strategy, RNA silencing does not constitute a panacea and a number of issues should be taken into consideration before being applied in the field. Noticeably, silencing based transgenic 
resistance is not influenced solely by the factors that were presented in this review. However, planting into areas where endemic virus diseases occur and mixed virus infections are expected especially during early stages of the vegetation period, time intervals of low air temperature and greenhouse or open field cultivation practices could affect the stability of transgenic resistance against plant viruses.

Further exploitation of our knowledge on RNA-silencing pathways is essential to improve the efficiency of the existing strategies or for the development of potential new strategies which will hopefully lead to a better reception by the public. Recent advances like the construction of chimeric IR constructs incorporating sequences derived from different virus species if combined with epidemiological data and pest risk analyses could reduce the effect of mixed virus infections on the resistance (Bucher et al., 2006; Dafny-Yelin \& Tzfira, 2007; Kung et al., 2009). Recently, virus resistance was achieved through expression of amiRNAS against viral coding sequences (Ding \& Voinnet, 2007; Duan et al., 2008; Niu et al., 2006; Qu et al., 2007; Simon-Mateo \& Antonio Garcia, 2006; Zhang et al, 2011). Although there was evidence that amiRNA-mediated virus resistance may not be inhibited by low temperature (Niu et al., 2006) this possibly depends on the plant species examined (Qu et al., 2007). Moreover, the durability of this approach, which resulted in relatively few antiviral small RNAs compared with those of the long dsRNA approach, needs to be further demonstrated (Duan et al., 2008; Simon-Mateo \& Antonio Garcia, 2006).

\section{Acknowledgement}

The author wishes to thank Christina Varveri for helpful discussions and for critically reading the manuscript, and to express his apologies to all those, whose papers were not cited.

\section{References}

Abel, P.P.; Nelson, R.S.; De, B.; Hoffmann, N.; Rogers, S.G.; Fraley, R.T. \& Beachy. R.N. (1986). Delay of disease development in transgenic plants that express the Tobacco mosaic virus coat protein gene. Science, Vol. 232, pp. 738-43

Bau, H.J.; Cheng, Y.H.; Yu, T.A.; Yang, J.S. \& Yeh, S.D. (2003), Broad-spectrum resistance to different geographic strains of Papaya ringspot virus in coat protein gene transgenic papaya. Phytopathology, Vol. 93, pp. 112-120

Binz, H.K. \& Plückthun, A. (2005). Engineered proteins as specific binding reagents. Current Opinon in Biotechnology, Vol.16, pp. 459-69

Blevins, T,; Rajeswaran, R.; Shivaprasad, P.V.; Beknazariants, D.; Si-Ammour, A.; Park, HS.; Vazquez, F.; Robertson, D.; Meins, Jr F.; Hohn, T. \& Pooggin M.M. (2006). Four plant Dicers mediate viral small RNA biogenesis and DNA virus induced silencing. Nucleic Acids Research, Vol. 34, pp. 6233-46

Brodersen, P. \& Voinnet, O. (2006). The diversity of RNA silencing pathways in plants. Trends in Genetics, Vol. 22, pp. 268-80

Brumin, M.; Stukalov, S.; Haviv, S.; Muruganantham, M.; Moskovitz, Y.; Batuman, O.; Fenigstein, A. \& Mawassi, M. (2009). Post-transcriptional gene silencing and 
virus resistance in Nicotiana benthamiana expressing a Grapevine virus A minireplicon. Transgenic Research, Vol.18, pp. 331-45

Bucher, E.; Lohuis, D.; van Popple, P.M.J.A.; Geerts-Dimitriadou, C.; Goldbach, R. \& Prins, M. (2006). Multiple virus resistance at a high frequency using a single transgene construct. Journal of General Virology, Vol. 87, pp. 3697-3701

Buchmann, R.C.; Asad, S.; Wolf, J.N.; Mohannath, G. \& Bisaro, D.M. (2009) Geminivirus AL2 and L2 Proteins Suppress Transcriptional Gene Silencing and Cause Genome-Wide Reductions in Cytosine Methylation. Journal of Virology, Vol. 83, pp. 5005-13

Chapman, E.J. \& Carrington, J.C. (2007). Specialization and evolution of endogenous small RNA pathways. Nature Reviews Genetics, Vol. 8, pp. 884-96

Chellappan, P.; Vanitharani, R.; Ogbe, F. \& Fauquet, C.M. (2005). Effect of Temperature on Geminivirus-Induced RNA Silencing in Plants. Plant Physiology, Vol.138, pp. 1828-41.

Dafny-Yelin, M. \& Tzfira, T. (2007). Delivery of Multiple Transgenes to Plant Cells. Plant Physiology, Vol.145, pp. 1118-28

Diaz-Pendon, J.A. \& Ding, S-W.(2008). Direct and Indirect Roles of Viral Suppressors of RNA Silencing in Pathogenesis. Annual Review of Phytopathology, Vol.46, pp. 30326

Ding, S.W. \& Voinnet, O. (2007). Antiviral immunity directed by small RNAs. Cell, Vol. 130, pp. 413-26.

Duan, C-G.; Wang, C-H. ; Fang, R-X. \& Guo, H-S. (2008). Artificial MicroRNAs Highly Accessible to Targets Confer Efficient Virus Resistance in Plants. Journal of Virology, Vol. 82, pp. 11084-95

Eamens, A.; Wang, M-B.; Smith, N.A. \&, Waterhouse, P.M. (2008). RNA Silencing in Plants: Yesterday, Today, and Tomorrow. Plant Physiology, Vol. 147, pp. 456-68

Farnham, G. \& Baulcombe, D.C. (2006). Artificial evolution extends the spectrum of viruses that are targeted by a disease-resistance gene from potato. Proceedings of National Academy of Science of USA, Vol.103, pp. 18828-33

Fuchs, M. \& Gonsalves, D. (2007). Safety of virus-resistant transgenic plants two decades after their introduction: lessons from realistic field risk assessment studies. Annual Review of Phytopathology, Vol.45, pp. 173-202

Fuentes, A.; Ramos, P.L.; Fiallo, E.; Callard, D.; Sanchez, Y.; Peral, R.; Rodrıguez, R. \& Pujol, M. (2006). Intron-hairpin RNA derived from replication associated protein C1 gene confers immunity to Tomato yellow leaf curl virus infection in transgenic tomato plants. Transgenic Research, Vol. 15, pp. 291-304

Gal-On, A.; Wolf, D.; Antignus, Y.; Patlis, L.; Ryu, K.H.; Min, B.E.; Pearlsman, M.; Lachman, O.; Gaba, V.; Wang, Y.; Shiboleth, Y.M.; Yang, J. \& Zelcer, A. (2005). Transgenic cucumbers harboring the $54-\mathrm{kDa}$ putative gene of Cucumber fruit mottle mosaic tobamovirus are highly resistant to viral infection and protect nontransgenic scions from soil infection. Transgenic Research, Vol. 14, pp. 81-93

Germundsson, A. \& Valkonen J.P.T. (2006). P1- and VPg-transgenic plants show similar resistance to Potato virus A and may compromise long distance movement of the 
virus in plant sections expressing RNA silencing-based resistance. Virus Research, Vol. 116, pp. 208-213

Hassani-Mehraban, A.; Brenkman, A.B.; van den Broek, N.J.F.; Goldbach, R. \& Kormelink, R. (2009). RNAi-Mediated Transgenic Tospovirus Resistance Broken by Intraspecies Silencing Suppressor Protein Complementation. Molecular Plant Microbe Interactions, Vol.22, pp. 1250-7

$\mathrm{Hu}$, Qiong.; Niu, Yanbing.; Zhang, Kai.; Liu, Yong. \& Zhou, Xueping. (2011). Virusderived transgenes expressing hairpin RNA give immunity to Tobacco mosaic virus and Cucumber mosaic virus. Virology Journal, Vol. 8, pp.:41

Hull, R. (2002) Matthews' Plant Virology. Academic Press, ISBN 0-12-361160-1, San Diego, USA

Jan, F-J.; Pang, S-Z.; Tricoli, D.M. \& Gonsalves, D. (2000). Evidence that resistance in squash mosaic comovirus coat protein-transgenic plants is affected by plant developmental stage and enhanced by combination of transgenes from different lines. Journal of General Virology, Vol. 81, pp. 2299-2306

Ji, L.H. \& Ding S.W. (2001). The suppressor of transgene RNA silencing encoded by Cucumber mosaic virus interferes with salicylic acid-mediated virus resistance. Molecular Plant Microbe Interactions, Vol.14, pp. 715-24

Jones, A.L.; Johansen, I.E.; Bean, S.J.; Bach, I. \& Maule, A.J. (1998). Specificity of resistance to pea seed-borne mosaic potyvirus in transgenic peas expressing the viral replicase (NIb) gene. Journal of General Virology, Vol. 79, pp. 3129-3137

Kalantidis, K.; Psaradakis, S.; Tabler, M. \& Tsagris, M. (2002). The occurrence of CMVspecific short RNAs in transgenic tobacco expressing virus-derived doublestranded RNA is indicative of resistance to the virus. Molecular Plant Microbe Interactions, Vol. 15, pp. 826-33

Kalantidis, K.; Schumacher, H.T.; Alexiadis, T. \& Helm, J.M. (2008). RNA silencing movement in plants. Biology of the Cell Vol. 100, pp. 13-26

Kang, B.C.; Yeam, I. \& Jahn, M.M. (2005). Genetics of plant virus resistance. Annual Review of Phytopathology, Vol.43, pp. 581-621

Kawazu, Y.; Fujiyama, R. \& Noguchi Y. (2009). Transgenic resistance to Mirafiori lettuce virus in lettuce carrying inverted repeats of the viral coat protein gene. Transgenic Research, Vol. 18, pp. 113-120

Kotakis, C.; Vrettos, N.; Kotsis , D.; Tsagris, M.; Kotzabasis K. \& Kalantidis, K.(2010). Light intensity affects RNA silencing of a transgene in Nicotiana benthamiana plants. BMC Plant Biology, Vol. 10, pp. 220

Kreuze, J.F.; Klein, I.S.; Lazaro, M.U.; Chuquiyuri, W.J.C.; Morgan, G.L.; Mejía, P.G.C.; Ghislain, M.\& Valkonen, J.P.T. (2008). RNA silencing-mediated resistance to a crinivirus (Closteroviridae) in cultivated sweetpotato (Ipomoea batatas L.) and development of sweetpotato virus disease following co-infection with a potyvirus. Molecular Plant Pathology, Vol. 9, pp. 589-98

Kung, Y.-J.; Bau, H.-J.; Wu, Y.-L.; Huang, C.-H.; Chen, T.-M. \& Yeh, S.-D. (2009). Generation of transgenic papaya with double resistance to Papaya ringspot virus and Papaya leaf-distortion mosaic virus. Phytopathology Vol. 99, pp.1312-1320 
Lecoq, H.; Moury, B.; Desbiez, C.; Palloix, A. \& Pitrat, M. (2004). Durable virus resistance in plants through conventional approaches: a challenge. Virus Research, Vol. 100, pp. 31-9

Lennefors, B-L.; van Roggen, P.M.; Yndgaard, F.; Savenkov, E.I. \& Valkonen J.P.T. (2007). Efficient dsRNA-mediated transgenic resistance to Beet necrotic yellow vein virus in sugar beets is not affected by other soilborne and aphid-transmitted viruses. Transgenic Research, Vol. 17, pp. 219-28

Lin, S-S.; Henriques, R.; Wu, H-W.; Niu. Q-W.; Yeh, S-D. \& Chua, N-H. (2007). Strategies and mechanisms of plant virus resistance. Plant Biotechnology Reports, Vol. 1, pp. 125-34

Lindbo, J.A.; Silva-Rosales, L.; Proebsting, W.M. \& Dougherty, W.G. (1993). Induction of a highly specific antiviral state in transgenic plants: implications for regulation of gene expression and virus resistance. Plant Cell, Vol. 5, pp. 1749-59

Lopez-Ochoa, L.; Ramirez-Prado, J. \& Hanley-Bowdoin, L. (2006). Peptide aptamers that bind to a geminivirus replication protein interfere with viral replication in plant cells. Journal of Virology, Vol. 80, pp. 5841-53

Missiou, A.; Kalantidis, K.; Boutla., A.; Tzortzakaki, S.; Tabler, M. \& Tsagris, M. (2004). Generation of transgenic potato plants highly resistant to Potato virus Y (PVY) through RNA silencing. Molecular Breeding, Vol. 14, pp. 185-97

Mitter, N.; Sulistyowati, E. \& Dietzgen, R.G. (2003). Cucumber mosaic virus infection transiently breaks ds-RNA-induced immunity to Potato virus $Y$ in tobacco. Molecular Plant Microbe Interactions, Vol. 16, pp. 936-44

Mitter, N.; Sulistyowati, E.; Graham, M.W. \& Dietzgen, R.G. (2001). Suppression of gene silencing: a threat to virus-resistant transgenic plants? Trends in Plant Science, Vol. 6, pp. 246-7

Mlotshwa, S.; Pruss, G.J. \& Vance, V. (2008). Small RNAs in viral infection and host defense. Trends in Plant Science, Vol. 13, pp. 375-82

Napoli, C.A.; Lemieux, C.; \& Jorgensen, R.A. (1990). Introduction of a Chimeric Chalcone Synthase Gene into Petunia results in reversible co-suppression of homologous genes in trans. Plant Cell, Vol.2, pp. 279-89

Nethra, P.; Nataraja, K.N.; Rama, N. \& Udayakumar, M. (2006). Standardization of environmental conditions for induction and retention of posttranscriptional gene silencing using tobacco rattle virus vector. Current Science, Vol. 90, pp. 431-435

Niu, Q-W.; Lin, S-S.; Reyes, J.L.; Chen, K-C.; Wu, H-W.; Yeh, S-D. \& Chua, N-H. (2006). Expression of artificial microRNAs in transgenic Arabidopsis thaliana confers virus resistance. Nature Biotechnology, Vol. 24, pp. 1420-8

Pasquinelli, A.E.; Hunter, S. \& Bracht, J. (2005). MicroRNAs: a developing story. Current Opinion in Genetics \& Development, Vol. 15, pp. 200-5

Praveen S.; Ramesh, S.V.; A. Z.; Mishra, A.K.; Koundal, V. \& Palukaitis, P. (2010). Silencing potential of viral derived RNAi constructs in Tomato leaf curl virus-AC4 gene suppression in tomato. Transgenic Research, Vol. 19, pp. 45-55

Prins, M.; De Haan, P.; Luyten, R.; Van Veller, M.; Van Grinsven, M.Q.J.M. \& Goldbach, R. (1995). Broad resistance to tospoviruses in transgenic plants by expressing three 
tospoviral nucleoprotein gene sequences. Molecular Plant Microbe Interactions, Vol. 8, pp. 85-91

Prins, M.; Laimer, M.; Noris, E.; Schubert, J.; Wassenegger, M. \& Tepfer, M. (2008). Strategies for antiviral resistance in transgenic plants. Molecular Plant Pathology, Vol. 1, pp. 73-83

Prins, M.; Lohuis, D.; Schots, A. \& Goldbach, R. (2005). Phage display selected singlechain antibodies confer high levels of resistance against Tomato spotted wilt virus. Journal of General Virology, Vol. 86, pp. 2107-13

Qu, J.; Ye, J. \& Fang, R. (2007). Artificial microRNA-mediated virus resistance in plants. Journal of Virology, Vol.81, pp. 6690-9

Ritzenthaler, C. (2005). Resistance to plant viruses: old issue, news answers? Current Opinion in Biotechnology, Vol. 16, pp. 118-22

Ronemus, M.; Vaughn, M.W. \& Martienssen, R.A. (2006). MicroRNA-Targeted and Small Interfering RNA-Mediated mRNA Degradation Is Regulated by Argonaute, Dicer, and RNA-Dependent RNA Polymerase in Arabidopsis. Plant Cell, Vol. 18, pp. 1559-74

Rudolph, C.; Schreier, P.H. \& Uhrig J.F. (2003). Peptide-mediated broad-spectrum plant resistance to tospoviruses. Procceedings of National Academy of Science of USA, Vol. 100, pp.4429-34

Ruiz-Ferrer, V. \& Voinnet, O. (2009). Roles of Plant Small RNAs in Biotic Stress Responses. Annual Review of Plant Biology, Vol. 60, pp. 485-510

Sanford, J.C. \& Johnston, S.A. (1985). The concept of pathogen derived resistance. Journal of Theoretical Biology, Vol. 113, pp. 395-405

Savenkov, E.I. \& Valkonen, J.P.T. (2001). Coat protein gene-mediated resistance to Potato virus $A$ in transgenic plants is suppressed following infection with another potyvirus. Journal of General Virology, Vol.82, pp. 2275-278

Schwab, R.; Ossowski, S.; Riester, M.; Warthmann, N. \& Weigel, D. (2006). Highly Specific Gene Silencing by Artificial MicroRNAs in Arabidopsis. Plant Cell, Vol. 18, pp. 1121-33

Schwind, N.; Zwiebel, M.; Itaya, A.; Ding, B.; Wang, M-B.; Krczal, G. \& Wassenegger, M. (2009). RNAi-mediated resistance to Potato spindle tuber viroid in transgenic tomato expressing a viroid hairpin RNA construct. Molecular Plant Pathology, Vol. 10, pp. 459-69

Seo, Y-S.; Rojas, M.R.; Lee, J-Y.; Lee, S-W.; Jeon, J-S.; Ronald, P.; Lucas, W.J. \& Gilbertson, R.L. (2006). A viral resistance gene from common bean functions across plant families and is up-regulated in a non-virus-specific manner. Procceedings of National Academy of Science of USA, Vol. 103, pp. 11856-61

Simon-Mateo, C. \& Antonio Garcia, J. (2006). MicroRNA-Guided Processing Impairs Plum Pox Virus Replication, but the Virus Readily Evolves To Escape This Silencing Mechanism. Journal of Virology, Vol. 80, pp. 2429-36

Simón-Mateo, C.; López-Moya, J.J.; Shan Guo, H.; González, E. \& García J.A. (2003). Suppressor activity of potyviral and cucumoviral infections in potyvirus-induced transgene silencing. Journal of General Virology, Vol. 84, pp. 2877-83 
Sos-Hegedus, A.; Lovas, A.; Kondrak, M.; Kovacs, G. \& Banfalvi, Z. (2005). Active RNA silencing at low temperature indicates distinct pathways for antisense-mediated gene-silencing in potato. Plant Molecular Biology, Vol. 59, pp. 595-602

Spassova, M.I.; Prins, T.W.; Folkertsma, R.T.; Klein-Lankhorst, R.M.; Hille, J.; Goldbach R.W. \& Prins, M. (2001). The tomato gene Sw-5 is a member of the coiled coil, nucleotide binding, leucine-rich repeat class of plant resistance genes and confers resistance to TSWV in tobacco. Molecular Breeding, Vol.7, pp. 151-61

Szittya, G.; Silhavy, D.; Molnar, A.; Havelda, Z.; Lovas, A.; Lakatos, L.; Banfalvi, Z. \& Burgyan, J. (2003). Low temperature inhibits RNA silencing-mediated defence by the control of siRNA generation. EMBO Journal, V. 22, pp. 633-40

Tavladoraki, P.; Benvenuto, E.; Trinca, S.; Demartinis, D.; Cattaneao, A. \& Galeffi, P. (1993). Transgenic plants expressing a functional single chain Fv antibody are specifically protected from virus attack. Nature, Vol. 366, pp. 469-72

Tenllado, F. \& Diaz-Ru1z J.R. (1999). Complete resistance to pepper mild mottle tobamovirus mediated by viral replicase sequences partially depends on transgene homozygosity and is based on a gene silencing mechanism. Transgenic Research, Vol. 8, pp. 83-93

Tenllado, F.; Llave, C. \& Diaz-Ru1z J.R. (2004). RNA interference as a new biotechnological tool for the control of virus diseases in plants. Virus Research, Vol. 102, pp. 85-96

Tennant, P.; Fermin, G.; Fitch, M.M.; Manshardt, R.M.; Slightom, J.L. \& Gonsalves, D. (2001). Papaya ringspot virus resistance of transgenic Rainbow and SunUp is affected by gene dosage, plant development, and coat protein homology. European Journal of Plant Pathology, Vol. 107, pp. 645-53

Thomashow, M.F., Nutter, R.; Montoya, A.L.; Gordon, M.P. \& Nester, E.W. (1980). Integration and organization of Ti plasmid sequences in crown gall tumors. Cell, Vol. 19, pp. 729-39

Uhrig, J.F. (2003). Response to Prins: broad virus resistance in transgenic plants. Trends in Biotechnology, Vol. 21, pp. 376-7

Van der Krol, A.R.; Mur, L.A.; Beld, M.; Mol, J.N.M. \& Stuitje, A. (1990). Flavonoid genes in petunia: addition of a limited number of gene copies may lead to a suppression of gene expression. Plant Cell, Vol.2, pp. 291-9

Vassilakos, N.; Bem, F.; Tzima, A.; Barker, H.; Reavy, B.; Karanastasi, E. \& Robinson, D.J. (2008). Resistance of transgenic tobacco plants incorporating the putative $57-\mathrm{kDa}$ polymerase read-through gene of Tobacco rattle virus against rub-inoculated and nematode-transmitted virus. Transgenic Research, Vol. 17, pp. 929-41

Vaucheret, H. (2006). Post-transcriptional small RNA pathways in plants: mechanisms and regulations. Genes \& Development, Vol. 20, pp. 759-71

Vaucheret, H.; Nussaume, L.; Palauqui, J.C. \& Quillere, I. \& Elmayan, T. (1997). A transcriptionally active state is required for post-transcriptional silencing (cosuppression) of nitrate reductase host genes and transgenes. Plant Cell, Vol. 9, pp. 1495-1504

Yang, Y.; Sherwood, T.A.; Patte, C.P.; Hiebert, E. \& Polston, J.E. (2004). Use of Tomato yellow leaf curl virus Rep gene sequences to engineer TYLCV resistance in tomato. Phytopathology, Vol. 94, pp. 490-6 
Zambryski, P.; Holsters, M.; Kruger, K.; Depicker, A.; Schell, J.; Van Montagu, M. \& Goodman, H.M. (1980). Tumor DNA structure in plant cells transformed by A. tumefaciens. Science, Vol. 209, pp. 1385-91

Zhang, X.; Li, H.; Zhang, J.; Zhang, C.; Gong, P.; Ziaf, K.; Xiao, F. \& Ye Z. (2011). Expression of artificial microRNAs in tomato confers efficient and stable virus resistance in a cell-autonomous manner. Transgenic Research, Vol. 20, pp. 569-581

Ziegler, A. \&, Torrance, L. (2002). Applications of recombinant antibodies in plant pathology. Molecular Plant Pathology, Vol.3, pp. 401-7 


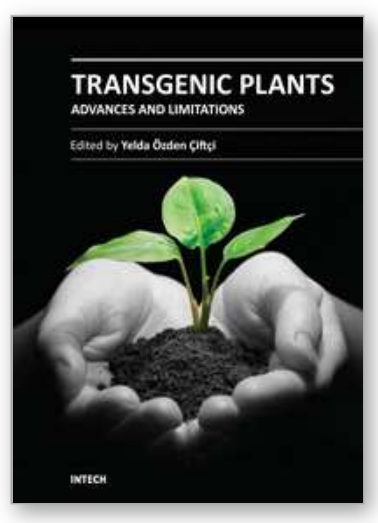

\author{
Transgenic Plants - Advances and Limitations \\ Edited by PhD. Yelda Ozden Çiftçi
}

ISBN 978-953-51-0181-9

Hard cover, 478 pages

Publisher InTech

Published online 07, March, 2012

Published in print edition March, 2012

Development of efficient transformation protocols is becoming a complementary strategy to conventional breeding techniques for the improvement of crops. Thus, Transgenic Plants - Advances and Limitations covers the recent advances carried on improvement of transformation methods together with assessment of the impact of genetically transformed crops on biosafety. Each chapter has been written by one or more experienced researchers in the field and then carefully edited to ensure throughness and consistency.

\title{
How to reference
}

In order to correctly reference this scholarly work, feel free to copy and paste the following:

Nikon Vassilakos (2012). Stability of Transgenic Resistance Against Plant Viruses, Transgenic Plants Advances and Limitations, PhD. Yelda Ozden Çiftçi (Ed.), ISBN: 978-953-51-0181-9, InTech, Available from: http://www.intechopen.com/books/transgenic-plants-advances-and-limitations/stability-of-transgenicresistance-against-plant-viruses

\section{INTECH}

open science | open minds

\section{InTech Europe}

University Campus STeP Ri

Slavka Krautzeka 83/A

51000 Rijeka, Croatia

Phone: +385 (51) 770447

Fax: +385 (51) 686166

www.intechopen.com

\section{InTech China}

Unit 405, Office Block, Hotel Equatorial Shanghai

No.65, Yan An Road (West), Shanghai, 200040, China

中国上海市延安西路65号上海国际贵都大饭店办公楼 405 单元

Phone: +86-21-62489820

Fax: $+86-21-62489821$ 
(C) 2012 The Author(s). Licensee IntechOpen. This is an open access article distributed under the terms of the Creative Commons Attribution 3.0 License, which permits unrestricted use, distribution, and reproduction in any medium, provided the original work is properly cited. 